Nikola Makojević ${ }^{1}$

Milan Stamenković ${ }^{2}$

Ljubina Kalinić ${ }^{3}$
JEL: L62

DOI: 10.5937/industrija45-14471

UDC:

Original Scientific Paper

\title{
Dispersion of automobile industry supplier network as precondition for regional underdevelopment? (comparative study Serbia, Italy and Czech Republic)
}

\author{
Article history: \\ Received: 7 July 2017 \\ Sent for revision: 25 July 2017 \\ Received in revised form: 11 October 2017 \\ Accepted: 11 October 2017 \\ Available online: 25 December 2017
}

\begin{abstract}
The aim of the paper is to analyze relationship between Fiat Automobile Industry supplier network, its geographical distribution and influence on regional development, and make comparison to similar situation in Italy and Czech Republic during automobile industry development. The industry in mentioned countries had and still have significant state support through subsides, taxes reliefs and employment programs, especially in regions defined as underdeveloped. The research results related with Italy and Czech Republic are opposite, because state supporting programs in Czech Republic gave positive results in automobile industry development and its relation with regional development. The regions with state supporting programs developed specific economy structure which resulted in their better position within national economy. On the other hand, case of Italy and its supporting programs showed inefficiency of state in regional development because most of the regions, after auto industry closing, experienced fall in GDP, employment and exports. The results of research showed consistency with Italian results, because found out strong concentration within Sumadija region along with low level of export orientation, making such region highly dependable on Fiat automobile industry. On the other hand, within Vojvodina region, such supplier network has been developed with export oriented
\end{abstract}

\footnotetext{
${ }^{1}$ University of Kragujevac,Faculty of Economics, nmakojevic@kg.ac.rs

${ }^{2}$,University of Kragujevac,Faculty of Economics

${ }^{3}$ Dirketna Banka
} 
Makojević N. et al.: Dispersion of automobile industry supplier network as...

suppliers, included in international automobile industry value chain, making the region more flexible and more resistant on future FIAT strategic decisions.

Keywords: automobile industry, supplier network, regional underdevelopment, foreign investment

\section{Razvoj mreže dobavljača u automobilskoj industriji kao predulov regionalnih neravnomernosti? (komparativna analiza Srbije, Italije i Češke republike)}

Apstrakt: Osnovni istraživački zadatak rada je analiza odnosa između mreže dobavljača Fiat automobili Srbija, njihove geografske lokacije i uticaja na regionalni razvoj, i poređenje sa sličnom situacijom u Italiji i Češkoj. Kada je reč o pomenutim zemljama, automobilska industrija je imala značajnu podršku od strane države u vidu subvencija, poreskih olakšica $i$ programa zapošljavanja naročito u regionima koji su nerazvijeni. Istraživanja su pokazala različite rezultate kada je reč o vezama automobilske insutrije $i$ regionalnog razvoja, tako da su u Češkoj zabeleženi pozitivni rezultati uticaja automobilske industrije na regionalni razvoj dok je u Italiji situacija drugačija jer su regioni, koji su koristili nacionalne programe za razvoj automobilske industrije, zabeležili pad u kretanju BDP-a, izvoza i zaposlenosti. Kada je reč o nacionalnoj ekonomiji, istraživanje je pokazalo snažnu koncentraciju dobavljača u regionu Šumadije, sa niskom orijentacijom ka izvozu, čime je zavisnost od Fiata značajna. S druge strane, dobavljači koncentrisani u regionu Vojvodine imaju značajne izvozne aktivnsoti, odnosno uključenost $u$ međunarodni lanac vrednosti automobilske industrije, čime ovaj region čine manje zavisnim od strateških odluke Fiat automobila Srbija.

Ključne reči: automobilska indutrija, mreža dobavljača, regionlna nerazvijenost, strane investicije

\section{Introduction}

The development of automotive industry in Serbia is related to long-term cooperation with Italian automobile manufacturer, which began in the sixties when a part of Italian technology and know-how were transferred to the newly established factory Zastava Automobiles in Kragujevac, the region of Šmadija. During 40 years, technology and development of the factory in Kragujevac fully relied on FIAT which meant that there was no significant development of components and technologies that were built into models manufactured. Zastava managed to produce 5 models which could not match the technology and quality of rival automobile models produced by FIAT itself, as well as other European manufacturers. As a result, the models were sold in 
Makojević N. et al.: Dispersion of automobile industry supplier network as...

underdeveloped countries' markets but also in domestic market, which was protected by the policy of high import duties on automobiles. Former government maintained a restrictive tariff policy concerning automotive industry, by defining high tariffs on the import of vehicles manufactured in other countries.With the collapse of socialism and the state, Zastava was facing the loss of market and increased competition, due to the removal of import barriers. In the mid-nineties, in a new state, tariff policy did not protect Zastava, and as a result high level of imports of used automobiles from Western Europe happened. Namely, one could buy a new Zastava model or used automobile from the EU manufacturers for the same price, where used automobiles had far more advanced systems and components.

The beginning of Serbian economy transition process during the 2000s has set a new challenge for economic policy makers. It was necessary to make a choice, either to shut down unprofitable factory or to find economically justified solution. As most authors concluded (Pavlínek, 2004; Pavlínek, Janak 2007), the importance of automotive industry is great for the national economy, therefore countries that had once declared themselves as socialist created support programs for attracting foreign direct investments in the automotive industry. Consequently, economic policy makers in Serbia in 2008 made a specific step, as a stimulant, which resulted in the conclusion of a contract between FIAT and the state of Serbia, establishing a joint venture in which the founding stake of FIAT and the state of Serbia included cash, technology, infrastructure, and regulatory framework.As a result of this state's initiative FAS was created, which currently produces one model, FIAT $500 \mathrm{I}$, which is mainly intended for foreign markets. At this point, the automotive industry is an important part of Serbian economy which generates more than two billion of annual revenue, which amounts to $4.6 \%$ of GDP. 85 companies that manufacture auto parts, employing over 25 thousand people, were registered in 2013 (Statistical Office of the Republic of Serbia, SIEPA).

\section{Literature review}

Research related to automotive industry in the former socialist countries, and its transformation through foreign direct investment, has quite important place in literature that measures economic development impulse (Havas, 1997; 2000a; 2000b; Czaban, Henderson, 1998; Tulder, Ruigrok, 1998; Richet, Bourassa, 2000; Pavlínek 2002a; 2002b; Domanski, 2003; Radosevic, Rozeik, 2005). Knowing the importance that automotive industry has on economic development, certain authors focused their research on regional distribution and network creation within national economy (Meyer, 2000; Pavlínek, 2003). The main reason for such research concentration can be found in "peripheral" position countries of Central and Eastern Europe 
Makojević N. et al.: Dispersion of automobile industry supplier network as...

obtained during automobile industry development within borders. Although auto industry increased its capacity and production, there is no enough evidence what happened with domestic producers and their position within regional and national economy (Pavlinek, Zenka, 2010). Knowing this, it is quite important for government of CEE countries to secure adequate position for domestic producers within automobile industry, by securing industrial upgrading and involvement in international value chain of automobile industry. As Kaplinsky $(2000,2005)$ defined upgrading is the only respond to the increased level of competitiveness in globalized economy and this means that industry needs to work on higher value-added products, more efficient production strategies and skills development. The main obstacle in value adding process is strict hierarchy which leaves limited possibilities for bottom position firms in process of upgrading and acquiring higher positions within network supplier network.

Special attention in the research is also given to the role of suppliers' network in the development of the region in which they are concentrated and depending on the position they occupy in relation to the distribution chain. Today's automotive industry is characterized by a network of suppliers who compete on price and quality to become a part of automobile manufacture process, which means that connections are made and broken relatively easily. Intense competition in the market requires the manufacture which has a competitive price, especially in the middle class vehicles market.

Skoda, as leading Czech automobile producer, had great impact on regional development influencing specific economic structure development. Some authors (Rugraf, 2010; Radosevic, et al., 2005, Tulder, 1998) argue that Czech-owned companies are totally absent from the first tier suppliers and are only linked by casual technological relationships to foreign-owned multinational subsidiaries. This kind of relationship has limited vertical spillovers of foreign owned multinational subsidiaries on the indigenous industry and increases the risk of the relocation of activities in foreign countries. Rugraf (2010) pointed out the effort Czech government is doing by encouraging different forms of cooperation between Czech and foreign entities, whether they are companies, universities or research institutes with little or no success. Others argue (Pavlinek, 2015) that Czech Republic continues to benefit from its geographic proximity to Germany, significantly lower labor costs than in Western Europe, a well-developed supplier base and increasing agglomeration economies.

Regarding FIAT, literature dealing with the organization of manufacture in the last few decades points to frequent changes of location and suppliers in manufacture process (Conti, Enirietti, 1995). During the process of moving, in the 60s and 70s, FIAT located its factories in Southern Italy with country's support, which significantly influenced changes in the economy of the region. 
Makojević N. et al.: Dispersion of automobile industry supplier network as...

Such offshoring has led to employment growth until the beginning of the 90s when it came to the decline and closure of factories that were located within the region of Turin (Withford, Enrietti, 2005). Data that encompass the period after 1990 show that the regions that have been characterized by a concentration of Tier 1, managed to survive the departure of FIAT as they have worked all time on market position strengthening regarding foreign automobile manufacturers. Withford and Enrietti (2005) conclude that involvement in international markets, and diversification of the risks arising from complete reliance on one manufacturer is of great importance concerning regional development.

The main research goal in paper is to analyze potential opportunities for regional disparities deepening in Serbian economy, as a result of poor distribution of FAS suppliers and their position in the supply chain. The paper is structured in such manner that first data was collected on the entire network of suppliers, their geographical location, and explored the possibility of relations between the location and belonging to a particular group (Tier) of suppliers. The research should contribute to the development of a new approach to planning and programs to attract foreign investment in the automotive industry.

\section{Research methodology}

Data collection, related to FAS supplier network, was carried out through several steps, starting with database at the disposal of state institutions such as the Serbia Investment and Export Promotion Agency (SIEPA), Automotive Cluster of Serbia, and Serbian Business Registers Agency, where each company must indicate activity code which identifies its main activity. After collecting the data, the questionnaire was designed for 21 companies targeted in the first phase of the research. Information from the survey led us to the conclusion that there are 19 more companies, which meant that the total sample of FAS suppliers was 40 . The second phase included the entire sample of FAS suppliers from Serbia. This kind of research is recognized in the literature, where researchers use qualitative methodologies based on case studies and interviews, directly with management of auto parts companies (Barnes, Kaplinsky 2000; Rutherford, 2000; Pavlínek, 2003; Pavlinek, Janak, 2007; Pavlínek, Zizalova, 2014).

The questionnaire itself is structured to provide information regarding ownership structure, establishment year, average monthly salary, key customers and suppliers. Furthermore, through the questionnaire and direct communication with suppliers' management the information concerning the final product placement was reached, i.e. what percentage is intended for 
Makojević N. et al.: Dispersion of automobile industry supplier network as...

domestic and what for foreign market, which was practically the answer to the question of how much production relies only on FAS.

In order to observe the regional dispersion of suppliers Serbia is divided into regions, at NUTS 2 level, which meant five regions one of which is Kosovo and Metohija, which was not included in the research because there were no investments related to automotive industry. This means that focus of research went towards the following NUTS 2 regions: Vojovodina, Belgrade, Šumadija and Western Serbia, and the region of Southern and Eastern Serbia. Within these regions we have grouped all 40 suppliers included in the research (Figure 1).

In order to simplify overview, suppliers are divided in three categories, according to their position in the process of delivering product directly or indirectly to the end user (Freyssenet et al., 1998; Pavlinek, Janak, 2007; Pavlínek, Domanski, Guzik, 2009; Pavlinek, Zizalova, 2014). In the literature, there are three groups of suppliers as defined by the following:

- First-tier suppliers (FTSs) are directly related to the automobile manufacturer. These are mostly large multinational companies that produce pre-assembled autonomous subsystems of components or modules (such as seats, doors, chassis or axles, systems for fuel injection, instrumental panels, exhaust systems, air conditioning, etc.). FTSs are mainly responsible for the design and development of products that are delivered directly to the manufacturer of the vehicle. R\&D is usually (but not always) located outside Serbia, in the country of corporate headquarters.

- Second-tier suppliers (STSs) are not directly related to the automobile manufacturer, but produce for FTSs. They produce smaller and less complex components from smaller parts (such as parts for dashboard, rubber parts, parts for air conditioning, etc.).

- Third-tier suppliers (TTSs) produce for the needs of STSs. They produce simple components with low value-added (such as rubber gaskets, hoses, insulation, simpler plastic parts, sheet steel, fastenings, screws). These simple components are usually delivered to STSs.

FAS suppliers are divided so that $45 \%$ are FTSs, $25 \%$ STSs, and $30 \%$ TTSs. According to the ownership structure, suppliers are divided to local suppliers, foreign suppliers, and suppliers of mixed ownership. When it comes to mixed ownership, three companies were registered of which two are of majority foreign ownership, therefore characterized as foreign companies. Of the total of 40 companies analyzed, 22 companies are foreign-owned (55\%), and 18 locally-owned $(45 \%)$. If the position in supplier category is looked, data show that $80 \%$ of foreign companies are grouped in FTSs, $10 \%$ in STSs, and $10 \%$ in TTSs. When it comes to companies of local ownership, only one is in FTSs group, while the others are divided between STSs (44\%) and TTSs (50\%). 
Makojević N. et al.: Dispersion of automobile industry supplier network as...

Figure. 1 The location of FAS Serbia suppliers in 2014

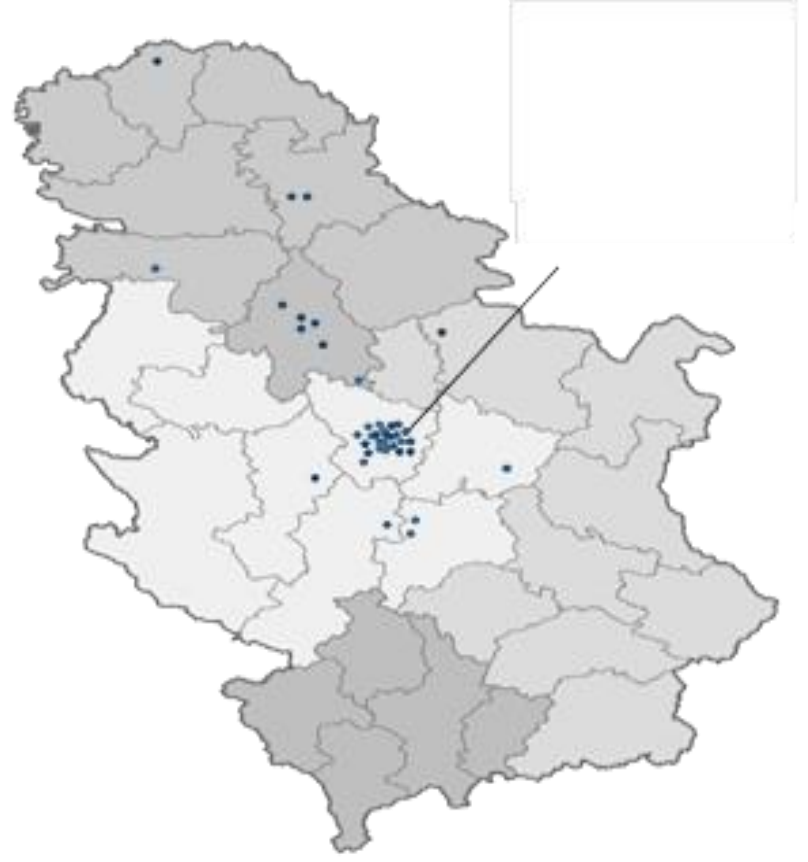

In research, which refers to determining statistically significant difference between the average distances (expressed in kilometers) of identified groups of suppliers from FAS corporate headquarters (Fiat Automobiles Serbia), the possibility of using One-way ANOVA was discussed, as a parametric statistical method intended for comparing arithmetic means of three or more data sets. In the context of the considered problem, a group of suppliers represents a categorical explanatory variable (factor) with three treatments (factor levels), or Tier 1, Tier 2, and Tier 3 while the distance of suppliers from FAS corporate headquarters represents a continuous numeric dependent variable

\section{Results and discussion}

As a parametric statistical method, valid implementation of ANOVA is based on meeting the assumptions on normality of population distribution to which drawn samples belong. Pursuant to the aforementioned, the testing of normality distribution of dependent variable for the selected groups of suppliers, was conducted using Shapiro-Wilk normality test (Table 1). 
Makojević N. et al.: Dispersion of automobile industry supplier network as...

Table 1: Results of normality tests

\begin{tabular}{|l|l|l|l|l|l|l|l|}
\hline \multirow{2}{*}{\multicolumn{2}{|c|}{ TIER }} & \multicolumn{4}{l|}{ Kolmogorov-Smirnov } & \multicolumn{2}{l|}{ Shapiro-Wilk } \\
\cline { 3 - 8 } & Statistic & df & Sig. & Statistic & df & Sig. \\
\hline \multirow{2}{*}{$\begin{array}{l}\text { Distance } \\
\text { (in km) }\end{array}$} & TIER 1 & 0.375 & 18 & 0.000 & 0.622 & 18 & 0.000 \\
\cline { 2 - 8 } & TIER 2 & 0.410 & 10 & 0.000 & 0.649 & 10 & 0.000 \\
\cline { 2 - 8 } & TIER 3 & 0.255 & 12 & 0.030 & 0.775 & 12 & 0.005 \\
\hline
\end{tabular}

Source: authors' calculations, SPSS 17.0

The presented results of Shapiro-Wilk normality test suggest that the assumption on normality of the distribution has not been confirmed in any of the considered groups of suppliers, since in all three cases the resulting $\mathrm{p}$ value is below the level of test significance $\alpha=0.05$. In order to better understand and explain obtained results, the values of descriptive statistics of discussed dependent variable (Table 2) and side-by-side boxplots of the sample data (Figure 2) were analyzed for each respective group of suppliers.

Table 2: Descriptive statistics for different groups of suppliers according to their distance from Fiat factory (in kilometers)

\begin{tabular}{|l|l|l|l|l|l|l|l|}
\hline \multicolumn{2}{|l|}{ TIER } & Mean & Median & $\begin{array}{l}\text { Std. } \\
\text { deviation }\end{array}$ & Min & Max & $\begin{array}{l}\text { Coefficient } \\
\text { of variation }\end{array}$ \\
\hline \multirow{2}{*}{$\begin{array}{l}\text { Distance } \\
\text { (in km) }\end{array}$} & TIER 1 & 60.33 & 2.95 & 105.69 & 1.0 & 333.0 & 175.19 \\
\cline { 2 - 8 } & TIER 2 & 22.75 & 6.95 & 27.71 & 2.8 & 64.0 & 121.80 \\
\cline { 2 - 8 } & TIER 3 & 76.46 & 75.75 & 69.84 & 2.3 & 156.0 & 91.34 \\
\hline
\end{tabular}

Source: authors' calculations, SPSS 17.0

Based on the mean values, relatively small difference in the average distance of suppliers in Tier 1 and Tier 3 group is clearly visible, although, according to the theoretical setting of the problem, a group of Tier 1 should include suppliers whose average distance from FAS corporate headquarters is significantly smaller than the average distance in other groups (especially Tier 3 group). Relatively high average values suggest the presence of outliers among the data, as evidenced by noticeable deviation of the value of arithmetic mean from median value as positional mean, especially present in Tier 1 and Tier 2 groups. The inherent resistance of the median to the presence of outliers in the data can be identified as the cause of clearly discernible difference in the values of the measures.

In addition to the above, the box-plot diagram for Tier 1 group confirms the presence of an outlier (the distance of Norma Group supplier) and several suspected outliers. Expressed heterogeneity (variability) of supplier's distance 
Makojević N. et al.: Dispersion of automobile industry supplier network as...

within the analyzed groups was confirmed by the high values of dispersion measure (std. deviation and coefficient of variation). Presented descriptive features of the three groups of data unambiguously confirm and explain the results in normality testing procedure

Figure 2: Box-plot diagram for different groups of suppliers

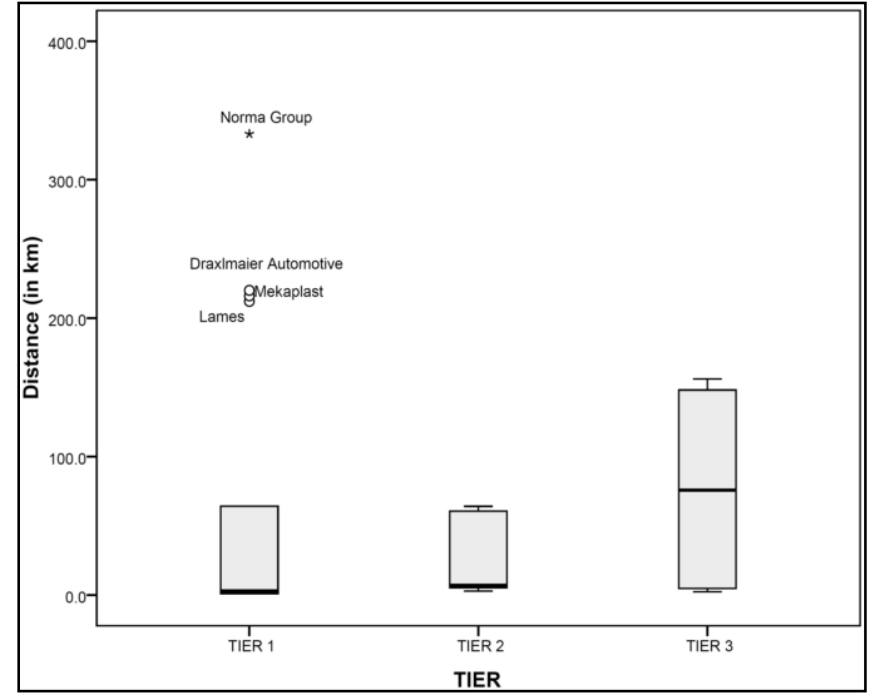

Since the basic assumption of applying One-way ANOVA has not been met (i.e. normality of the underlying population distribution), for the purposes of testing the impact of explanatory variable - the group of suppliers (with three treatments - Tier 1, Tier 2, and Tier 3) and dependent variable -distance from FAT corporate headquarters (in $\mathrm{km}$ ) the Kruskal-Wallis $\mathrm{H}$ test was used, as a nonparametric alternative procedure to (analog of) the $\mathrm{F}$ statistic used within parametric One-way ANOVA. The idea behind the Kruskal-Wallis test is that, as a nonparametric method, it relies on the ranks of dependent variable values and the means of those ranks, rather than on the examining of means of the data. Kruskal-Wallis $\mathrm{H}$ test statistic is calculated using the following formula:

$$
H=\frac{12}{N+(N+1)} \sum_{i=1}^{k} \frac{R_{i}^{2}}{n_{i}}-3(N+1)
$$

where:

$N$ is the total number of observations, i.e. $N=\sum n_{i}($ for $i=1,2, \ldots, k)$;

$n_{i}$ denotes the number of observations in the $i$-th sample; and 
Makojević N. et al.: Dispersion of automobile industry supplier network as...

$R_{i}^{2}$ denotes the sum of ranks of the $i$-th sample (for $i=1,2, \ldots, k$ ).

In the context of the considered problem ( $\left.N=40, k=3, n_{1}=18, n_{2}=10, n_{3}=12\right)$, the null and alternative hypotheses can be defined as follows:

$\mathrm{H}_{0}$ : There is no statistically significant difference between the medians of supplier's distance within Tier1, Tier 2, and Tier 3 group from FAS corporate headquarters;

$\mathrm{H}_{1}$ : There is statistically significant difference between medians of supplier's distance from FAS corporate headquarters in at least two Tier groups.

More specifically, based on side-by-side boxplots and median values presented in Figure 1 and Table 2, respectively, it can be noticed that the median for Tier 3 group of suppliers is much higher than the sample medians of the other two groups, while the median value for Tier 1 group is slightly smaller than the corresponding value for Tier 2 group. In order to investigate whether these differences are statistically significant or are attributable to random choice, the Kruskal-Wallis was conducted test using a 0.05 significance level. Obtained results are presented in Table 3 and Table 4.

Table 3: Mean Ranks and Medians for different groups of suppliers

\begin{tabular}{|l|l|l|l|l|}
\hline \multicolumn{2}{|l|}{} & $\mathrm{n}$ & Mean Rank & Median \\
\hline \multirow{3}{*}{ Distance (in km) } & TIER 1 & 18 & 16.69 & 2.95 \\
\cline { 2 - 5 } & TIER 2 & 10 & 21.50 & 6.95 \\
\cline { 2 - 5 } & TIER 3 & 12 & 25.38 & 75.75 \\
\hline \multicolumn{2}{|l|}{ Total } & 40 & $/$ & $/$ \\
\hline
\end{tabular}

Source: authors' calculations, SPSS 17.

Table 4: Results of the Kruskal-Wallis $\mathrm{H}$ testa

\begin{tabular}{|l|l|}
\hline & Distance (in kilometers) \\
\hline Chi-Square test & 4.101 \\
\hline $\mathrm{df}$ & 2 \\
\hline $\mathrm{p}$-value & 0.129 \\
\hline a. Grouping variable: TIER \\
\hline
\end{tabular}

Source: authors' calculations, SPSS 17.0

As it can be seen in Table 3 and 4, since the obtained p-value (0.129) is much greater than the $\alpha=0.05$ level of significance, the null hypothesis cannot be rejected, and therefore conclude that there is not sufficient evidence to indicate that the distributions of supplier's distance from FAS headquarters for the three groups of suppliers (Tier 1, Tier 2 and Tier 3 ) are different. More precisely, there is not enough evidence to claim that the differences between 
Makojević N. et al.: Dispersion of automobile industry supplier network as...

median values of supplier's distance from FAS headquarters for the observed Tier groups are statistically significant.

If research include the coefficient of efficiency (location) in the analysis, analytical statistic that measures a region's industrial specialization relative to a national, the results obtained may be a good assumption for further planning of regional economic development. An LQ is computed as an industry's share of a regional total for some economic statistic (earnings, GDP by metropolitan area, employment, etc.) divided by the industry's share of the national total for the same statistic:

$$
L Q_{i, t}=\frac{R E_{i, t} / T R E_{i, t}}{N E_{i, t} / T N E_{i, t}}
$$

where $L Q_{i, t}$ is the location quotient of industry $i$ at time $t, R E_{i, t}$ is the regional employment of industry $i$ at time $t, T R E_{i, t}$ is the total regional employment of industry $i$ at time $t, N E_{i, t}$ is the national employment of industry $i$ at time $t$ and $T N E_{i, t}$ is the total national employment of industry $i$ at time $t$.

Data relating to the $L Q$ show a strong concentration of the region in which FAS is situated, because the value of the coefficient is 4.014, while the same coefficient in the other two regions in which suppliers are located is significantly smaller, and ranges at the level of 2.80 in one region and at the level of 0.46 in the other. This practically means that the region in which FAS is situated has tremendous dependence on the business success and development strategies of FAS. The situation is more alarming when considering that the region with 4.014 is the region that has the lowest level of economic development measured by the achieved GDP, compared to the NUTS 2 level.

\section{Conclusion}

By applying the appropriate methodology, the research has shown that there is no statistically significant relation between the distance of supplier and its belonging to the group of FTS, STS, or TTS. These research results are the consequence of large dispersion within FTS group, which is the result of the existence of suppliers located 333 kilometers from FAS, while the maximum distance within TTS group is only $156 \mathrm{~km}$. Research results show that suppliers, when making investment decisions, did not find location and geographical position in relation to FAS important. To understand such supplier's manner of thinking, it is necessary to analyze data from the questionnaire on their sales production program concentration. 
Makojević N. et al.: Dispersion of automobile industry supplier network as...

The absence of a connection between the location and belonging to a group is the result of certain companies' strategies to assign a part of their production for export purposes. Companies that are extremes in terms of their geographic location are the companies that export more than $50 \%$ of their production, which means that developed infrastructure in terms of traffic communication, such as highways, ports, railways, and airports, is crucial to their location. In this way, regions in which these companies are concentrated are less susceptible to changes that FAS' business can bring, while it is quite contrary for the regions in which suppliers whose production relies entirely on FAS are concentrated.

As a result of the research, the conclusion that arises shows the lack of state's efficiency in planning the strategy of attracting foreign investment in the automotive industry, since it allowed the creation of conditions for further deepening of regional disparities. The concentration of Tier 1 in the region of Sumadija, which relies only on the production of FAS, is an excessive reliance on one manufacturer which creates a serious potential for deepening regional disparities. Moreover, Tier 1, which are not concentrated only on the production of FAS, chose better infrastructural equipped region of Vojvodina for their location, thereby making the region in a better position.

These results provide solid base for comparison with Czech Republic and Italy in process of developing supplier network within automobile industry, and possibilities for future underdevelopment at regional level. The results are showing lack of adequate coordination between national and local authorities in the process of network creation, which created conditions for high dependence on single automobile producer. Such result should be used as recommendations for economic policy makers to think about active measures to attract another automobile manufacturer in the region of Šumadija, in order to reduce extreme dependence on FAS and prevent the occurrence of further regional disparities in case of the change in FAS business policy.

\section{Literature}

Barnes, J. and Kaplinsky, R. (2000) 'Globalization and the Death of the Local Firm? The Automobile Components Sector in South Africa', Regional Studies 34: 797812.

Conti, S., Enirietti, A., (1995), The Italian automobile industry and the case of Fiat: on country, one company, one market? in: Towards new map of automobile manufacturing in Europe: new production concepts and spatial restructuring, Springer

Czaban, L. and Henderson, J. (1998) 'Globalization, Institutional Legacies and Industrial Transformation in Eastern Europe', Economy and Society 27: 585-613. 
Makojević N. et al.: Dispersion of automobile industry supplier network as...

Domanski B. (2003) Industrial change and foreign direct investment in the postsocialist economy The Case Of Poland, European Urban and Regional Studies 10(2): 99118

Freyssenet, M., Mair, A., Shimizu, K. and Volpato, G. (1998) One Best Way? Trajectories and Industrial Models of the World's Automobile Producers. Oxford: Oxford University Press.

Havas, A. (1997) 'Foreign Direct Investment and Intraindustry Trade: the Case of the Automotive Industry in Central Europe', in D. Dyker (ed.) The Technology of Transition, pp. 211-40. Budapest: Central European University Press.

Havas, A. (2000a) 'Local, Regional and Global Production Networks: Reintegration of the Hungarian Automotive Industry', in C. Von Hirschhausen and J. Bitzer (eds) The Globalization of Industry and Innovation in Eastern Europe: from Postsocialist Restructuring to International Competitiveness, pp. 95-127. Cheltenham and Northampton, MA: Edward Elgar.

Havas, A. (2000b) 'Changing Patterns of Inter- and Intra- Regional Division of Labour: Central Europe's Long and Winding Road', in J. Humphrey, Y. Lecler and M.S. Salerno (eds) Global Strategies and Local Realities: the Auto Industry in Emerging Markets, pp. 234-62. Houndsmill, London and New York: Macmillan and St Martin's Press.

Kaplinsky, R. (2000) Globalisation and unequalisation: what can be learned from value chain analysis?. Journal of Development Studies, 37: 117-146

Kaplinsky, R., Readman, J. (2005) Globalization and upgrading: what can (and cannot) be learnt from international trade statistics in the wood furniture sector?, Industrial and Corporate Change, 14: 679-703

Meyer, K.E. (2000) 'International Production Networks and Enterprise Transformation in Central Europe', Comparative Economic Studies 42: 135-50.

Pavlınek, P., Zenka,J., (2010), "Upgrading in the automotive industry: firm-level evidence from Central Europe", Journal of Economic Geography, 1-28

Pavlínek, P. (2003) 'Transformation of the Czech Automotive Components Industry through Foreign Direct Investment', Eurasian Geography and Economics 44: 184209.

Pavlínek, P. (2004) 'Regional Development Implications of Foreign Direct Investment in Central Europe', European Urban and Regional Studies 11 (1): 47-70.

Pavlinek P, Žížalová P. (2014) Linkages and spillovers in global production networks: Firm-level analysis of the Czech automotive industry, Journal of economic geography $16(2): 331-363$

Pavlınek, P., Janak, L. (2007) Regional restructuring of the Skoda Auto supplier network in the

Czech Republic. European Urban and Regional Studies, 14: 133-155.

Pavlınek, P., Domanski, B., Guzik, R. (2009) Industrial upgrading through foreign direct investment in Central European automotive manufacturing. European Urban and Regional Studies, 16: 43-63.

Pavlínek, P. (2002a) 'Transformation of Central and East European Passenger Car Industry: Selective Peripheral Integration through Foreign Direct Investment', Environment and Planning A 34: 1685-709.

Pavlínek, P. (2002b) 'Restructuring the Central and Eastern European Automobile Industry: Legacies, Trends and Effects of Foreign Direct Investment', Post- Soviet Geography and Economics 43: 41-77. 
Makojević N. et al.: Dispersion of automobile industry supplier network as...

Pavlinek, P., (2015), Foreign direct investment and the development of the automotive industry in Central and Eastern Europe, Foreign investment in eastern and southern Europe after 2008: Still a lever of growth? edited by Béla Galgóczi, Jan Drahokoupil, Magdalena Bernaciak

Radosevic, S., Rozeik, A. (2005) 'Foreign Direct Investment and Restructuring in the Automotive Industry in Central and East Europe', Working Paper 53, Centre for the Study of Economic and Social Change in Europe, University College London.

Richet, X. and Bourassa, F. (2000) 'The Reemergence of the Automotive Industry in Eastern Europe', in C. Von Hirschhausen and J. Bitzer (eds) The Globalization of Industry and Innovation in Eastern Europe: from Postsocialist Restructuring to International Competitiveness, pp. 59-94. Cheltenham and Northampton, MA: Edward Elgar.

Rugraf, E.,(2010), FDI and Supplier-Oriented Upgrading in the Czech Motor Vehicle Industry, Regional Studies, Vol.44, Issue 5, 627-638

Tulder, R. and Ruigrok, W. (1998) 'International Production Networks in the Auto Industry: Central and Eastern Europe as the Low End of the West European Car Complexes', in J. Zysman and A. Schwartz (eds) Enlarging Europe: the Industrial Foundations of a New Political Reality, pp. 202-37, University of California International and Area Studies Digital Collection, Research Series

Withford, Enrietti, (2005), Surviving the Fall of a King: The Regional Institutional Implications of Crisis at Fiat Auto, International Journal of Urban and Regional Research, Volume 29, Issue 4, pages 771-795, 